\title{
ASSOCIATION BETWEEN ELEVATED HIGH SENSITIVITY CARDIAC-TROPONIN I LEVELS AND INCREASE IN LEVELS OF C-REACTIVE PROTEIN, INTERLEUKIN-6, D-DIMER, AND CONSEQUENT CARDIAC INJURY AND MORTALITY FOR PATIENTS WITH CORONAVIRUS DISEASE 2019: A META-ANALYSIS
}

\author{
DHEAA SHAMIKH ZAGEER ${ }^{1}$, SUNDUS FADHIL HANTOOSH ${ }^{2 *}$, WATHIQ Q SH. ALI ${ }^{3}$ \\ ${ }^{1}$ Forensic DNA Center for Research and Training, Al-Nahrain University, Baghdad, Iraq. ${ }^{2}$ Department of Training and Development, \\ Forensic DNA Center for Research and Training, Al-Nahrain University, Baghdad, Iraq. ${ }^{3}$ Department of Applied Embryology, High Institute \\ of Infertility Diagnosis and ART, Al-Nahrain University, Baghdad, Iraq. Email: sundus.alnahi@gmail.com
}

Received: 18 March 2021, Revised and Accepted: 25 April 2021

ABSTRACT

Objectives: This meta-analysis aims to investigate the role of high sensitivity-cardiac troponin I (hs-cTnI) as a prognostic factor for cardiac injury and as a risk factor of death for patients with coronavirus disease 2019 (COVID-19). This meta-analysis studies the impact of hs-cTnI elevated levels on C-reactive protein (C-RP) protein, interleukin-6 (IL-6), and D-dimer (DD) levels in COVID-19 affected individuals.

Methods: Of 557 downloaded articles according to chosen criteria for this meta-analysis, 11 were finally chosen as they met the criteria.

Results: Male and elderly individuals were noticeably prone to COVID-19 infection and considerably underwent death in comparison with female and young individuals. Levels of hs-cTn I, C-RP, IL-6, and DD were significantly higher among dead compared to survivors for COVID-19 affected individuals.

Conclusions: Levels of C-RP, IL-6, and DD were considerably high and in linear relation with elevated hs-cTn I levels. Hs-cTn I can be considered a reliable marker for COVID-19 infection prognosis and potent predictor of decease.

Keywords: High sensitivity-cardiac troponin I, Cardiac injury, C-reactive protein, Interleukin-6, D-dimer, Death.

(C) 2021 The Authors. Published by Innovare Academic Sciences Pvt Ltd. This is an open access article under the CC BY license (http://creativecommons.org/ licenses/by/4.0/) DOI: http://dx.doi.org/10.22159/ajpcr.2021v14i6.41491. Journal homepage: https://innovareacademics.in/journals/index.php/ajpcr

\section{INTRODUCTION}

Coronavirus disease 2019 (COVID-19) serious complications include respiratory failure or heart failure, stroke, dysfunction of other organs of body, and decease [1].

Following myocardial cell decay, unbound cytoplasmic troponin (Tn) is liberated from cardiac myocytes leading to elevation of Tn levels in blood [2].

Results found that C-reactive protein (C-RP) production in coronary smooth muscle cells was in reaction to inflammatory cytokines [3]. Interleukin-6 (IL-6) stimulates production of C-RP [4].

D-dimer (DD) is a soluble fibrin decaying output that comes from ordered collapse of thrombi by coagulative and fibrinolytic system [5]. Higher concentrations of circulating DD are existent in circumstances related to thrombosis [6].

\section{METHODS}

\section{Search strategy}

We suppose that we illustrated all required data sufficiently, please be accepted as it is. A systematic search was done by using "hscTn I" and "mortality" with each: "heart failure," "myocardial infarction," "myocarditis," "pericarditis," "cardiac injury," and "coronary artery disease."

Searched databases comprised PubMed-NCBI, PMC-NCBI, and Catholic University of America, university Libraries-Google Scholar

The following original research articles were involved: Prospective observational, retrospective, retrospective observational, retrospective analysis, and case-control study.
The period of original research articles was from December 25, 2019 to April 20, 2020.

\section{Criteria indicated for study selection}

Studies met the following criteria were involved:

1. Studies mentioning characteristics of hospitalized COVID-19 affected individuals

2. COVID-19 affirmed by chest computed tomography scan, reverse transcriptase-polymerase chain reaction lab test, and hallmarks of illness

3. Cardiac injury was described as blood concentrations of cardiac biomarker cardiac troponin I (cTnI), elevated above $99^{\text {th }}$ the percentile upper reference limit

4. Studies documented higher high sensitivity-cardiac troponin I (hs-cTn I) concentrations, cardiac complications, and consequent deceases for COVID-19 hospitalized affected individuals

5. Altered biomarkers values of DD, C-RP, and IL-6 as a consequence of rise in hs-cTnI concentrations; measurement of these biomarkers was according to affirmed laboratory examinations.

The articles were excluded if they were: Meta-analysis, narrative reviews, reviews, review and meta-analysis, systemic reviews, editorial comment, case-based review, commentary, to the editor, editorial, letter to the editor, short communication, researches not dealing with COVID-19, case study, position statement complement, literature review, research article not in English, case presentation, and COVID-19 opinion.

Finally, the total number of uploaded articles with duplications was 557; the total number of articles met the criteria and with duplicated ones was 260; the number of duplicated articles that met the criteria was 174; the total number of original articles excluded after excluding duplications 109; the number of articles met the criteria after exclusion 
of duplications was 86, and after all exclusions; and the total number of research articles enrolled in this meta-analysis was 11.

\section{Statistical analysis}

In all studies included in this meta-analysis: categorical variables were identified by frequency and percentages and continuous variables were mentioned as means \pm standard deviation for normally distributed data and medians for non-normally distributed data. In addition, patient characteristic was compared using Chi-square tests or Fischer exact tests for categorical variables. Moreover, a two-sample t-test was used to assess whether there were significant differences in continuous variables when they were normally distributes. Further, univariate analysis was performed to describe significant variables correlated with cardiac injury and demise on hospital admission. Statistical analyses were considered significant if $\mathrm{p} \leq 0.05$.

\section{Ethics considered}

For all studies included in this meta-analysis oral consents of all patients were obtained. These studies were approved by Hospital Institutional Ethics Committee of each hospital enrolled in this metaanalysis. Written informed consent was waived due to rapid emergence of COVID-19 contagion.

\section{RESULTS}

Table 1 showed notable increase in number of death among COVID-19 affected patients and that males were more susceptible to be infected with this disease and more vulnerable to death in comparison with females.

Table 2 indicated that elderly COVID-19 affected individuals were significantly vulnerable to decease in comparison with other ages.

Table 3 revealed that hs-cTn I levels were considerably elevated among deceased COVID-19 contracted individuals compared to survivors.

Table 4 exhibited that hs-cTnI levels were considerably elevated among COVID-19 affected individuals experienced cardiac injury complications in comparison with those did not.

Tables 5-7 demonstrated noticeable increase in levels of C-RP, IL-6, and DD among deceased COVID-19 patients compared to survivors, respectively. Elevated levels of C-RP, IL-6, and DD were accompanied by noticeable elevation in levels of hs-cTnI in cases included in this metaanalysis.

\section{DISCUSSION}

Advantageous information propose high-rise predisposition of males to COVID-19 contagion in comparison with females [18]. A study, in Italy declared that COVID-19 decease average in males was $16.6 \%$ in males in comparison with $9.1 \%$ in females [19].

Elevated smoking percent is in male and it is correlated with COVID-19 seriousness [18]. Proofs presumed elevated hazard of contagion and retrieval of viral contagions in the upper respiratory tract among smokers in comparison with non-smokers [18]. Angiotensin-converting enzyme 2 (ACE2) is considered a principle regulatory component of renin angiotensin system (RAS) and participates noticeably in kidney, heart, and gastrointestinal tract physiology [18]. Smith et al. (2020) recognized change in ACE2 expression in different epithelial cells lining respiratory tract in reaction to tobacco [20]. Expression of ACE2 was noticed to be elevated in tobacco smoking persons in comparison with non-smokers [18]. Attachment of severe acute respiratory syndrome coronavirus-2 (SARS-CoV-2) to ACE2 favors its entrance into host cells [18]. Therefore, upregulation of ACE2 effectiveness or expression may boost predisposition to SARS-CoV-2 contagion and seriousness of this illness [18].

Various literatures showed prevailing model of suppressed immune response in males attributed to existence of testosterone (T) hormone [18]. Activity of testosterone hormone results in decreased adaptive immune response attributing to suppressed action of associated type 2 T-helper cells and type 17-T-helper cells, and in consequence lowered antibody $(\mathrm{Ab})$ responses and $\mathrm{B}$ cell propagation [18]. These circumstances attributed to decreased synthesis of efficient immunoglobulin G, in males as compared to females which might be predisposed to worst prediction [21].

Researches consider that noticeable populace of COVID-19 contracted persons complain cytokine storms (CS) [18]. Proof describes that males are more susceptible for promoted synthesis of pro-inflammatory cytokines in comparison with females [22].

Table 1: Characteristics of patients in studies enrolled in this meta-analysis

\begin{tabular}{|c|c|c|c|c|c|c|c|c|}
\hline S. No. & Author & Place & Duration & Study type & $\begin{array}{l}\text { Total } \\
\text { patients' } \\
\text { number }\end{array}$ & $\begin{array}{l}\text { Alive } \\
\text { patients } \\
\text { number }\end{array}$ & $\begin{array}{l}\text { Dead } \\
\text { patients } \\
\text { number }\end{array}$ & Gender (\%) \\
\hline 1. & Heng et al. [7] & China & $\begin{array}{l}\text { January 21, to April 18, } \\
2020\end{array}$ & $\begin{array}{l}\text { Prospective } \\
\text { observational }\end{array}$ & 51 & 39 & $12(23.5 \%)$ & Male: 37 (72.50) \\
\hline 2. & Chen et al. [8] & Wuhan, China & February 3 to 20,2020 & Retrospective & 73 & 53 & $20(27.40 \%)$ & Male: $42(57.50)$ \\
\hline 3. & Zhang et al. [9] & Wuhan, China & $\begin{array}{l}\text { December 25, } 2019 \text { to } \\
\text { February 15, } 2020\end{array}$ & Retrospective & 48 & $31(64.60 \%)$ & $17(35.40 \%)$ & Male:33 (68.80) \\
\hline 5. & Shi et al. [11] & Wuhan, China & $\begin{array}{l}\text { January } 1 \text { to February } \\
23,2020\end{array}$ & Retrospective & 671 & 609 & 62 & Male: $322(48.00)$ \\
\hline 6. & Zhang et al. [12] & Wuhan, China & $\begin{array}{l}\text { February } 7 \text { to March } \\
27,2020\end{array}$ & Retrospective & 53 & 40 & 13 & NA \\
\hline 7. & Raad et al. [13] & $\begin{array}{l}\text { South East } \\
\text { Michigan, USA }\end{array}$ & $\begin{array}{l}\text { March } 9 \text { to April 15, } \\
2020\end{array}$ & Retrospective & 1020 & 840 & 180 & $\begin{array}{l}\text { Female: } 511 \\
(50.00)\end{array}$ \\
\hline 8. & Zhu et al. [14] & Wuhan, China & $\begin{array}{l}\text { January } 12 \text { to February } \\
28,2020\end{array}$ & $\begin{array}{l}\text { Retrospective } \\
\text { analysis }\end{array}$ & 64 & 24 & 40 & Male: 36 \\
\hline 9. & Song et al. [15] & Wuhan, China & $\begin{array}{l}\text { February } 4 \text { to March } \\
3,2020\end{array}$ & $\begin{array}{l}\text { Retrospective } \\
\text { observational }\end{array}$ & 64 & 17 & $47(73.40 \%)$ & Male: $42(65.60)$ \\
\hline 10. & Pan et al. [16] & Wuhan, China & $\begin{array}{l}\text { January } 27 \text { to March } \\
19,2020\end{array}$ & Case-control & 124 & 35 & $89(71.80 \%)$ & Male: 85 (68.50) \\
\hline 11. & $\begin{array}{l}\text { Barman et al. } \\
\text { [17] }\end{array}$ & $\begin{array}{l}\text { Istanbul, } \\
\text { Turkey }\end{array}$ & $\begin{array}{l}\text { March } 20 \text { to April 20, } \\
2020\end{array}$ & Retrospective & 607 & 504 & 103 & Male: 334 \\
\hline
\end{tabular}

S.: Sequence 


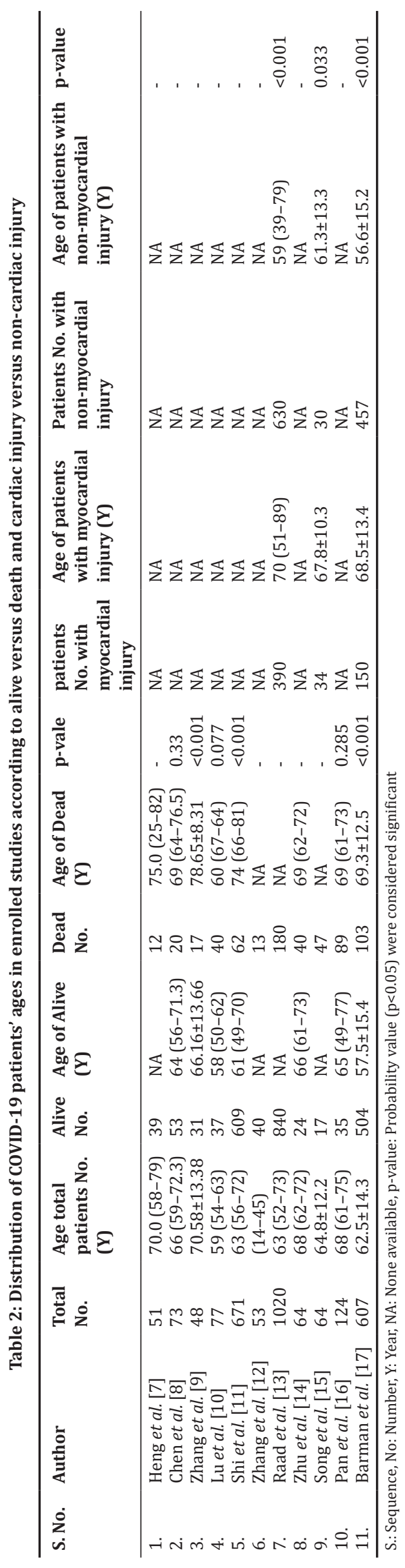

Among COVID-19 contracted individuals, elderly ones have higher demise proportion due to raised case fatality rate and symptomatic contagion average [23]. It was found that about $80 \%$ and $90 \%$ of deceases happened in ill individuals aged more than 70 years and equal to or more than 60 years in Korea and Italy, respectively [23]. Age impacts time from hospitalization to decease and viral clearance [23]. In immunopathology, susceptibility to contagion in elderly persons is typically interpreted by immunosenescence [23]. In senility, production of naïve $\mathrm{T}$ and $\mathrm{B}$ cells lowers, and action of innate immune cells is declined; for this reason cells included in innate immunity do not get invigorated effectively during contagion, and development to adaptive immune response does not happen in regulated pattern [23]. These alterations decrease efficiency of viral clearance and elevate probability of provoking dysregulated immune response in a way that cytokines are released widely by activated immune cells, leading to CS [24]. Another recognizable characteristic of senile immunity is chronic subclinical systemic inflammation, also called inflammaging [23]. Inflammation is a basic pathogenic tool in COVID-19; thus, inflammaging has been predicted to contribute to worse result in elderly COVID-19 affected individuals [23]. In addition, mean measure of comorbid events steadily raise with age [23]. More than one-third of aged adults' raised decease hazard was mediated by bad lung function, hypertension, muscle weakness, and multiple long-term conditions (multiple LTCs) [25]. Among aged participants, these considerations were both more common and more potentially correlated with raised COVID-19 death percent [25].

Works by Huang et al. (2020) and Guo et al. (2020) not only described that recognizable number of hospitalized ill individuals identified with COVID-19 presented cardiac injury (exemplified by higher levels of cardiac biomarkers such as Tn), but that ones who progressed cardiac injury had noticeably raised death rate than those without [26,27].

Sick individuals with signals of cardiac injury were at raised hazard of demise both during period from symptom emergence and from admission to end point, assuming that associated biomarkers such as hs-cTn I may offer predictive information early on and throughout illness development [28]. Initial monitoring of cardiac injury-related biomarkers, involving hs-cTn I, may take part considerably in decreasing hazard of decease in grave circumstance [29]. Search articles shed light that cardiac deterioration happens with COVID-19-associated high Tn concentrations [30]. Tn I was regarded as primary considerable estimator of decease [30]. A valuable search article showed, in-line with the previous literature, Tn concentrations were presented to be highrise in aged sick persons and males [30]. A study conducted by Shi et al. (2020) recognized death rate was $51.2 \%$ in ill persons with elevated Tn concentrations and cardiac deterioration and $4.5 \%$ in ill ones without cardiac injury [31].

High-rise of Tn concentrations in COVID-19 affected individuals is interpreted by a number of potential mechanization [30]. These are: first, viral myocarditis; second, cytokine-induced myocardial damage; third, microangiopathy; and fourth, unmasked coronary artery disease [30]. SARS-CoV-2 spike (S) glycoprotein attaches ACE2 receptors for entrance into target cell [30]. ACE2 is exceedingly found in pericytes of adult human hearts [30]. Further, for entry target cell with ACE2, COVID-19 decreases return of angiotensin II (Ang II) to angiotensin 1-7 (Ang 1-7) by restraining ACE2 synthesis [30]. Ang 1-7 generates protective cardiovascular (CV) influences in targeted organs of body [30]. In consequence, restrain of ACE2 synthesis and succeeding high-rise in Ang II concentrations may construct an impendence to heart and vessels in COVID-19 affected individuals [30]. Endothelial dysfunction, CSs, and Ang II upregulation can interpret usual incidence of coagulopathy in intense COVID-19 [30]. Oxidative stress, which is featured by raised production of reactive oxygen species and free radicals succeeded by lowered serum total antioxidant concentrations, can clarify usual incidence of coagulopathy in intense COVID-19 [30,32].

Yao et al. (2020) declared that ill individuals in male group and 60-79 years age groups incline to generate raised hs-cTn I levels than 
Table 3: hs-cTnI levels in COVID-19 cases enrolled in the studies included in this meta-analysis distributed according to alive versus death

\begin{tabular}{|c|c|c|c|c|c|c|c|c|c|}
\hline S. No. & Author & $\begin{array}{l}\text { Total } \\
\text { cases } \\
\text { No. }\end{array}$ & $\begin{array}{l}\text { Reference or cut- } \\
\text { off levels }\end{array}$ & $\begin{array}{l}\text { hs-cTnI levels in } \\
\text { total cases }\end{array}$ & $\begin{array}{l}\text { Alive } \\
\text { No. }\end{array}$ & $\begin{array}{l}\text { hs-cTnI levels in } \\
\text { alive }\end{array}$ & $\begin{array}{l}\text { Dead } \\
\text { No. }\end{array}$ & $\begin{array}{l}\text { Hs-cTnI levels in } \\
\text { dead }\end{array}$ & p-value \\
\hline 1. & Heng et al. [7] & 51 & NA & $\begin{array}{l}0.07 \mathrm{ng} / \mathrm{ml} \\
(0.02-0.23) \mathrm{ng} / \mathrm{ml}\end{array}$ & 39 & $\begin{array}{l}0.07 \mathrm{ng} / \mathrm{ml} \\
(0.02-0.18) \mathrm{ng} / \mathrm{ml}\end{array}$ & 12 & $\begin{array}{l}0.20 \mathrm{ng} / \mathrm{ml} \\
(0.03-0.54) \mathrm{ng} / \mathrm{ml}\end{array}$ & 0.039 \\
\hline 2. & Chen et al. [8] & 73 & NA & $\begin{array}{l}10.2 \mathrm{pg} / \mathrm{ml} \\
(5.3-22.5) \mathrm{pg} / \mathrm{ml}\end{array}$ & 53 & $\begin{array}{l}7.2 \mathrm{pg} / \mathrm{ml} \\
(5.0-15.2) \mathrm{pg} / \mathrm{ml}\end{array}$ & 20 & $\begin{array}{l}32.3 \mathrm{pg} / \mathrm{ml} \\
(10.3-176.0) \mathrm{pg} / \mathrm{ml}\end{array}$ & 0.000 \\
\hline 3. & Zhang et al. [9] & 48 & $\begin{array}{l}\text { Upper reference } \\
\text { limit: } 0.026 \mathrm{ug} / \mathrm{L}\end{array}$ & $0.012 \mathrm{ug} / \mathrm{L}$ & 31 & $0.006 \mathrm{ug} / \mathrm{L}$ & 17 & $0.034 \mathrm{ug} / \mathrm{L}$ & 0.001 \\
\hline 4. & Lu et al. [10] & 77 & Cut-off: $\leq 15.6 \mathrm{pg} / \mathrm{ml}$ & $\begin{array}{l}13.0 \mathrm{pg} / \mathrm{ml} \\
(3.4-111.3) \mathrm{pg} / \mathrm{ml}\end{array}$ & 37 & $\begin{array}{l}3.6 \mathrm{pg} / \mathrm{ml} \\
(2.1-10.1) \mathrm{pg} / \mathrm{ml}\end{array}$ & 40 & $\begin{array}{l}41.5 \mathrm{pg} / \mathrm{ml} \\
(12.1-308.6) \mathrm{pg} / \mathrm{ml}\end{array}$ & $<0.001$ \\
\hline 5. & Shi et al. [11] & 671 & $\begin{array}{l}\text { Normal reference: } \\
(0.0-0.04) \mathrm{ng} / \mathrm{ml}\end{array}$ & $\begin{array}{l}0.006 \mathrm{ng} / \mathrm{ml} \\
(0.006-0.016) \mathrm{ng} / \mathrm{ml}\end{array}$ & 609 & $\begin{array}{l}0.006 \mathrm{ng} / \mathrm{ml} \\
(0.006-0.011) \\
\mathrm{ng} / \mathrm{ml}\end{array}$ & 62 & $\begin{array}{l}0.235 \mathrm{ng} / \mathrm{ml} \\
(0.042-1.996) \\
\mathrm{ng} / \mathrm{ml}\end{array}$ & $<0.001$ \\
\hline 6. & Zhang et al. [12] & 38 & NA & $\begin{array}{l}2.10 \mathrm{pg} / \mathrm{ml} \\
(1.90-4.45) \mathrm{pg} / \mathrm{ml}\end{array}$ & 27 & $\begin{array}{l}1.90 \mathrm{pg} / \mathrm{ml} \\
(1.90-2.30) \mathrm{pg} / \mathrm{ml}\end{array}$ & 11 & $\begin{array}{l}19.45 \mathrm{pg} / \mathrm{ml} \\
(12.55-98.67) \\
\mathrm{pg} / \mathrm{ml}\end{array}$ & $3.2 \times 10^{5}$ \\
\hline 7. & Zhu et al. [14] & 64 & NA & NA & 24 & $(0.02-0.03) \mathrm{ug} / \mathrm{L}$ & 40 & $\begin{array}{l}0.03 \mathrm{ug} / \mathrm{L} \\
(0.03-0.07) \mathrm{ug} / \mathrm{L}\end{array}$ & 0.007 \\
\hline 8. & Pan et al. [16] & 124 & $<26.2 \mathrm{ug} / \mathrm{L}$ & $\begin{array}{l}19.3 \text { ug/L (8.4-96.4) } \\
\text { ug/L }\end{array}$ & 35 & $\begin{array}{l}9.9 \mathrm{ug} / \mathrm{L} \\
(3.4-57.1) \mathrm{ug} / \mathrm{L}\end{array}$ & 89 & $\begin{array}{l}24.1 \mathrm{ug} / \mathrm{L} \\
(9.8-155.8) \mathrm{ug} / \mathrm{L}\end{array}$ & 0.006 \\
\hline 9. & Barman et al. [17] & 607 & $\begin{array}{l}\text { Upper reference } \\
\text { limit: } 14 \mathrm{pg} / \mathrm{ml}\end{array}$ & $\mathrm{NA}$ & 504 & $\begin{array}{l}10 \mathrm{pg} / \mathrm{ml} \\
(5-15) \mathrm{pg} / \mathrm{ml}\end{array}$ & 103 & $\begin{array}{l}41 \mathrm{pg} / \mathrm{ml} \\
(14-157) \mathrm{pg} / \mathrm{ml}\end{array}$ & $<0.001$ \\
\hline
\end{tabular}

S.: Sequence, No.: Number, hs-cTn I: High sensitivity-cardiac troponin I, NA: Non-available, ng/ml: Nanogram/milliliter, pg/ml: Pictogram/milliliter, ug/L: Microgram/ liter, $\mathrm{p}$-value: Probability value $(\mathrm{p}<0.05)$ were considered significant

Table 4: hs-cTnI levels in cases with cardiac injury versus those with no cardiac injury in studies enrolled in this meta-analysis

\begin{tabular}{|c|c|c|c|c|c|c|c|c|}
\hline $\begin{array}{l}\text { S. } \\
\text { No. }\end{array}$ & Author & $\begin{array}{l}\text { hs-cTnI levels in normal } \\
\text { or cut-off levels }\end{array}$ & $\begin{array}{l}\text { Total } \\
\text { cases } \\
\text { No. }\end{array}$ & $\begin{array}{l}\text { No. of Cases } \\
\text { with cardiac } \\
\text { injury }\end{array}$ & $\begin{array}{l}\text { hs-cTnI levels in } \\
\text { cardiac injury cases }\end{array}$ & $\begin{array}{l}\text { No. of cases } \\
\text { with no } \\
\text { cardiac injury }\end{array}$ & $\begin{array}{l}\text { hs-cTnI levels } \\
\text { in non-cardiac } \\
\text { injury cases }\end{array}$ & p-value \\
\hline 1. & Shi et al. [11] & Normal: $0-0.04 \mathrm{ng} / \mathrm{ml}$ & 671 & 106 & $\begin{array}{l}0.159 \mathrm{ng} / \mathrm{ml} \\
(0.075-0.695) \mathrm{ng} / \mathrm{ml}\end{array}$ & 565 & $\begin{array}{l}0.006 \mathrm{ng} / \mathrm{ml} \\
(0.006-0.007) \\
\mathrm{ng} / \mathrm{ml}\end{array}$ & $<0.001$ \\
\hline 2. & Raad et al. [13] & Cut-off:>18 ng/L & 1020 & NA & 43 ng/L (27-87) ng/L & NA & $\begin{array}{l}8.0 \mathrm{ng} / \mathrm{L} \\
(2.3-14) \mathrm{ng} / \mathrm{L}\end{array}$ & $<0.001$ \\
\hline 3. & Song et al. [15] & Normal: $\leq 34.2 \mathrm{ng} / \mathrm{L}$ & 64 & 34 & $\begin{array}{l}276.1 \mathrm{ng} / \mathrm{L} \\
(139.1-909.7) \mathrm{ng} / \mathrm{L}\end{array}$ & 30 & $\begin{array}{l}12.1 \mathrm{ng} / \mathrm{L} \\
(4.7-18.9) \mathrm{ng} / \mathrm{L}\end{array}$ & $<0.001$ \\
\hline 4. & Barman et al. [17] & $\begin{array}{l}\text { Upper reference } \\
\text { limit:14 pg/ml }\end{array}$ & 607 & 150 & $\begin{array}{l}97 \mathrm{pg} / \mathrm{ml} \\
(42-300) \mathrm{pg} / \mathrm{ml}\end{array}$ & 457 & $\begin{array}{l}9 \mathrm{pg} / \mathrm{ml} \\
(5-13) \mathrm{pg} / \mathrm{ml}\end{array}$ & $<0.001$ \\
\hline
\end{tabular}

S.: Sequence, hs-cTn I: High sensitivity cardiac troponin I, No.: Number, ng/ml: Nanogram/milliliter, ng/L: Nanogram/liter, pg/ml: Pictogram/milliliter, p-value: Probability value $(\mathrm{p}<0.05)$ were considered significant

female and other age groups, which was in agreement with all raised percent of aged male deceased [5].

It was found that Tn concentrations were associated with concentrations of inflammatory biomarkers [33]. Plasma hs-Tn I concentrations were positively associated with plasma IL-6 concentrations, plasma highsensitivity C-RP concentrations, plasma DD concentrations, and plasma brain natriuretic peptide concentrations [33]. It was demonstrated that for COVID-19 affected persons, in line with higher DD concentrations, high-rise $\mathrm{Tn}$ concentration, up to $36 \mathrm{pg} / \mathrm{ml}$ on hospital admission were prognostic of decease [33]. It was documented that higher lactate dehydrogenase (LDH), C-RP, and decreased lymphocytes counts were bound with raised death rates in infected persons with COVID-19 [34,35]. Higher values of cell death factors such as liver enzymes, LDH, DD, and Tn I refer to that COVID-19 CS is exemplified by noticeable systemic tissue decay that in various affected individuals may strike liver, the CV system, and kidneys [36]. Elevated values of DD were recorded in number of cohort studies of sick persons with COVID-19 and associated with higher death rate [37].

IL-6 possesses noticeable positive relation with Tn I, C-RP, ferritin, and procalcitonin (PCT) [38]. Immune responses anomaly takes critical role in pathogenesis of a number of illnesses, involving viral contagions [38]. Many secreted cytokines from induced immune cells take part in antiviral immune response mechanism. Their raised and uncontrolled concentrations attribute to tissue injuries [38]. A number of original articles recorded elevated concentrations of IL- 6 in COVID-19 contracted individuals with serious complications [39]. There are two attributable causes can be presumed for elevated concentrations of IL-6 in COVID-19 affected individuals: Viral contagion and angiotensin (Ang)II receptors' induction [38]. A study revealed that mice contagion with SARS-CoV led to recognizably lowered ACE2 production in lungs [40]. ACE2 controls Ang II concentrations by converting it to heptapeptide [38]. The resulting decrease of ACE2 and high-rise in Ang II might drive IL-6 synthesis and release [38]. Much synthesis of IL-6 leads to pathological anomalies [38]. Besides pro-inflammatory action, IL-6 has anti-inflammatory characteristics and adjusts a number of features of immune system, involving hematopoiesis, aggregation of neutrophils, synthesis and secretion of adhesion components, and synthesis of chemokines and their receptors [38]. Defensive action of IL-6 restricts neutrophil recruitment and replacement of mononuclear cells [38]. Findings of this research clarified that neutrophil and monocyte counts had downward and upward slopes under $60 \mathrm{pg} / \mathrm{ml}$ of IL- 6 while mechanism of neutrophil and monocyte changes reversed in COVID-19 
Table 5: High-sensitivity C-reactive protein levels for alive versus dead COVID-19 cases in the studies enrolled in this meta-analysis

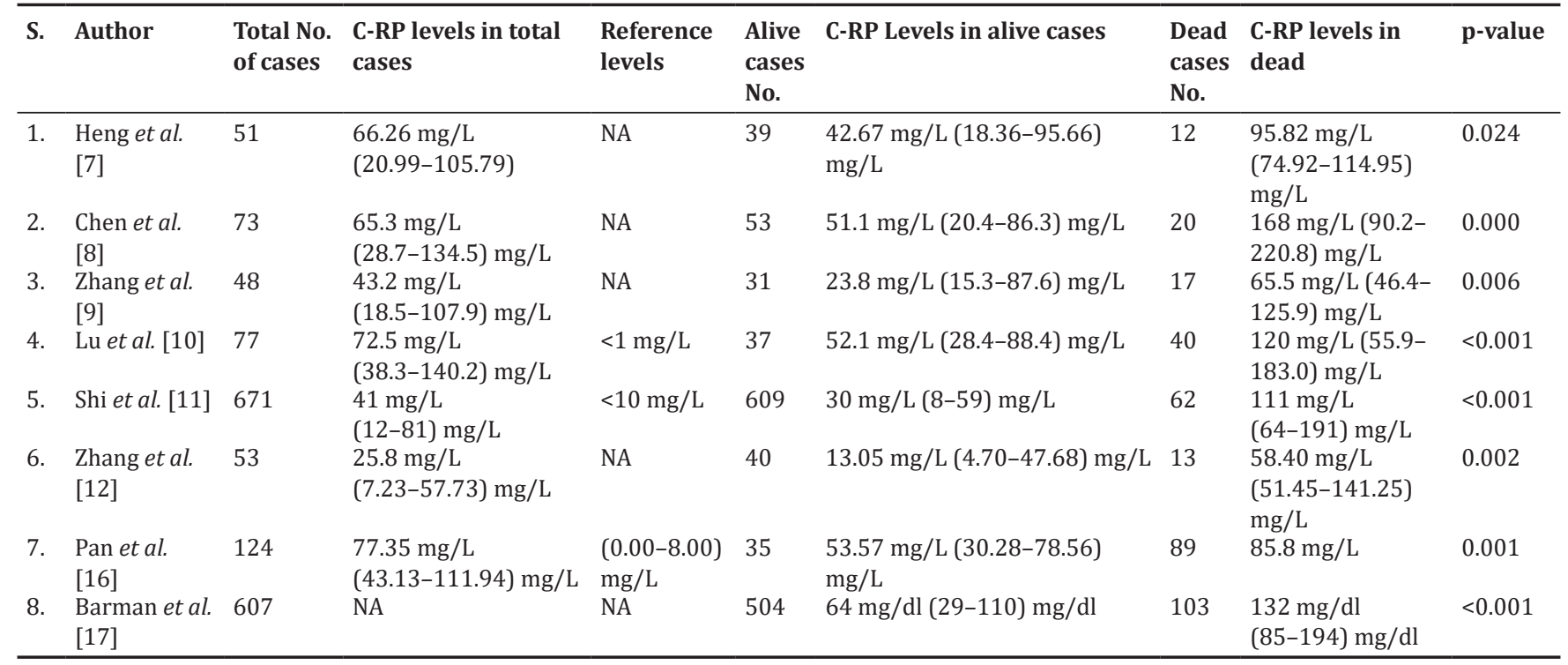

S.: Sequence, No.: Number, C-RP: C-reactive protein, p-value: Probability value, $(\mathrm{p}<0.05)$ were considered significant, NA: Non-available, mg/L: Milligram/liter, mg/dL: Milligram/deciliter

Table 6: Interleukin-6 levels in alive versus dead COVID-19 cases measurements in studies enrolled in this meta-analysis

\begin{tabular}{|c|c|c|c|c|c|c|c|c|c|}
\hline S. & Author & $\begin{array}{l}\text { Cases } \\
\text { total } \\
\text { No. }\end{array}$ & $\begin{array}{l}\text { Reference } \\
\text { Levels }\end{array}$ & IL-6 levels in total cases & $\begin{array}{l}\text { Alive } \\
\text { No. }\end{array}$ & IL-6 levels in alive & $\begin{array}{l}\text { Dead } \\
\text { No. }\end{array}$ & IL-6 levels in dead & p-value \\
\hline 1. & Heng et al. [7] & 51 & NA & $\begin{array}{l}39.81 \mathrm{pg} / \mathrm{ml}(10.0- \\
674.38) \mathrm{pg} / \mathrm{ml}\end{array}$ & 39 & $\begin{array}{l}19.48 \mathrm{pg} / \mathrm{ml}(7.43- \\
68.48) \mathrm{pg} / \mathrm{ml}\end{array}$ & 12 & $\begin{array}{l}1071.39 \mathrm{pg} / \mathrm{ml} \\
(463.82-1820.50) \\
\mathrm{pg} / \mathrm{ml}\end{array}$ & $<0.001$ \\
\hline 2. & Chen et al. [8] & 73 & NA & $\begin{array}{l}35.5 \mathrm{pg} / \mathrm{ml}(13.2-81.9) \\
\mathrm{pg} / \mathrm{ml}\end{array}$ & 53 & $\begin{array}{l}27.2 \mathrm{pg} / \mathrm{ml}(12.6-62) \\
\mathrm{pg} / \mathrm{ml}\end{array}$ & 20 & $\begin{array}{l}84.3 \mathrm{pg} / \mathrm{ml}(22.6- \\
137.8) \mathrm{pg} / \mathrm{ml}\end{array}$ & 0.011 \\
\hline 3. & Zhang et al. [12] & 34 & NA & $\begin{array}{l}11.27 \mathrm{pg} / \mathrm{ml}(2.11-20.91) \\
\mathrm{pg} / \mathrm{ml}\end{array}$ & 27 & $\begin{array}{l}9.50 \mathrm{pg} / \mathrm{ml}(1.79- \\
18.09) \mathrm{pg} / \mathrm{ml}\end{array}$ & 7 & $\begin{array}{l}22.88 \mathrm{pg} / \mathrm{ml}(18.90- \\
27.76) \mathrm{pg} / \mathrm{ml}\end{array}$ & 0.117 \\
\hline
\end{tabular}

S.: Sequence, No.: Number, NA: Non-available, IL-6: Interleukin-6, pg/ml: Pictogram/milliliter, p-value: Probability value, (p<0.05) were considered significant

Table 7: D-dimer levels for alive versus dead COVID-19 cases measurements in studies included in this meta-analysis

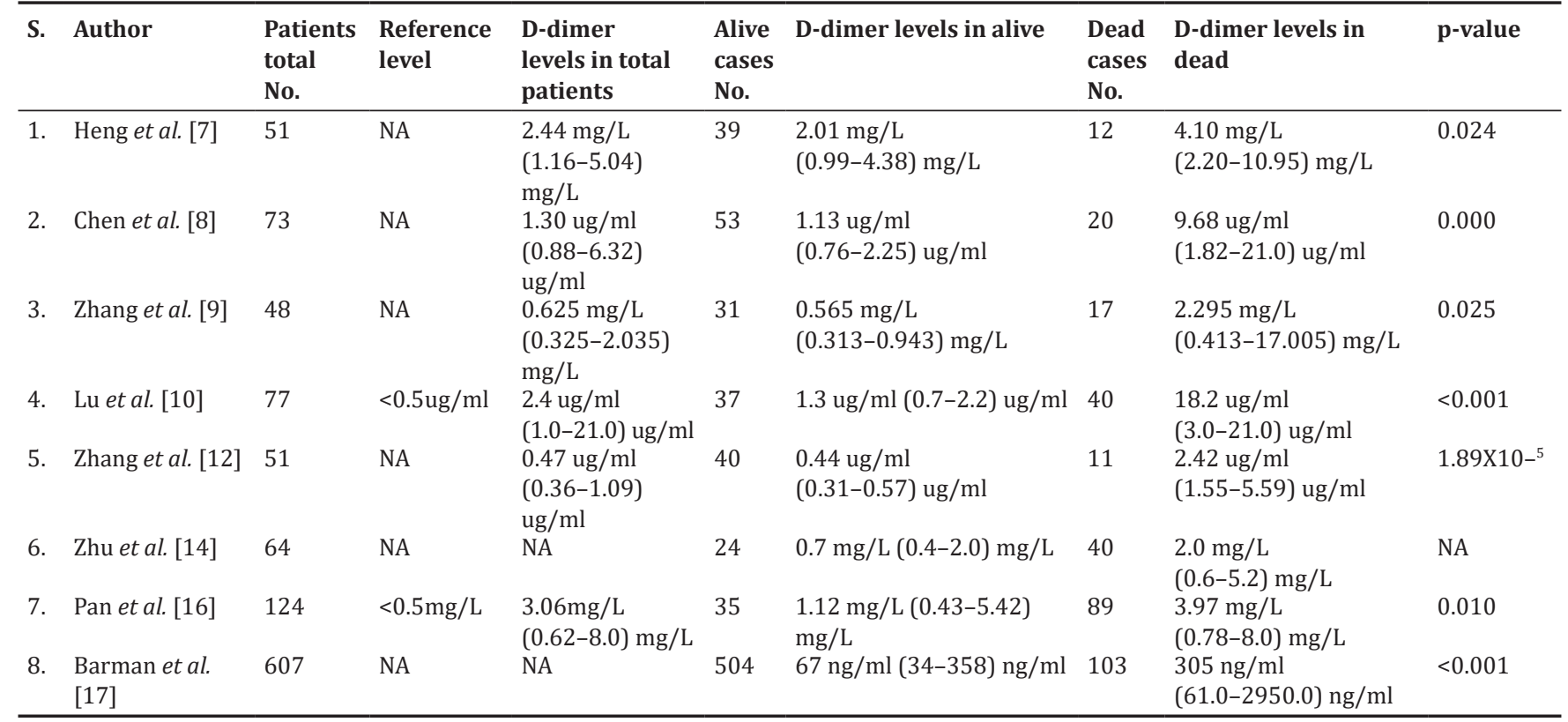

S.: Sequence, No.: Number, NA: Non-available, mg/L: Milligram/liter, ug/ml: Microgram/milliliter, p-value: Probability value, (p<0.05) were considered significant 
infected persons with more than $60 \mathrm{pg} / \mathrm{ml}$ (ten-fold of normal range) of IL-6 [38]. Continuation of acute phase and neutrophil aggregation results in tissue deterioration [38]. Number of research articles proposed that lymphopenia and cytokine release syndrome (CRS) were combined with seriousness of illness; cytokine release syndrome (CRS) is systemic inflammatory response that can be provoked by different conditions, such as contagions, toxins, or idiosyncratic response to medications, and is exemplified by high-rise in concentrations of pro-inflammatory cytokines, involving IL-6 [41]. This known as CS may speedily result in single or multiple organ dysfunction syndromes (MODS) and is identified to specify not only acuteness but also predicting COVID-19 progression [41]. Elevated IL-6 concentrations were recognized among deceased cases from COVID-19 in comparison with survived cases [39].

Yao et al. (2020) administered that there was considerable association between atypical hs-cTn I levels and DD concentrations [5]. About half of affected individuals with COVID-19 have raised DD concentrations, which is correlated with illness gravity and elevated death averages [42]. Guo et al. (2020) reported that DD concentrations were considerably raised in group with elevated $\mathrm{Tn}$ concentrations than in group with normal $\mathrm{Tn}$ concentrations [27]. Huang et al. (2020) concentrated that imbalance of $\mathrm{T}$ helper 1 and $\mathrm{T}$ helper 2 immune responses in ill individuals with COVID-19 resulted in a CS and attributed to myocardial injury [30]. Cytokines, resulted from circulating systemic inflammation, generate type 1 myocardial infarction (type $1 \mathrm{MI}$ ), causing thrombus formation, atherosclerotic plaque instability, and disruption [30]. Of interest, Guo et al. (2020) mentioned that no ill persons presented acute myocardial infarction (MI) findings at admittance to hospital [27]. Decrease levels of Ang 1-7 in consequence to ACE2 receptor downregulation resulted from COVID-19 elevates incidence of CSs, which can lead to intense inflammatory response associated with myocardial destruction and contagion [30]. In searches achieved by Shi et al. (2020) and Guo et al. (2020) and Lin et al. (2020), noticeable positive linear correlation was existent between plasma Tn and C-RP concentrations, assuming that myocardial destruction can be exceedingly correlated with inflammatory pathogenesis $[27,31,43]$. On the same, a notable study revealed that C-RP levels were noted to be elevated in high Tn I group [30]. In addition, Guo and Lin et al. declared that, in serious COVID-19 ill persons, ferritin, $\mathrm{LDH}$, and DD values were elevated and lymphocyte counts were lowered than in cases without serious illness $[31,43]$.

Biochemical markers take crucial role in precise diagnosis and also for estimating gravity and choosing therapy that boosts clinical outcome [44].

\section{CONCLUSIONS}

Male and elderly individuals with COVID-19 were more susceptible to poor outcomes and death than female and young individuals experienced COVID-19. hs-cTn I levels were significantly higher among COVID-19 individuals with cardiac injury compared with without cardiac injury ones. Higher hs-cTn I levels were accompanied by significant increase in levels of C-RP, IL-6, and DD among COVID-19 affected individuals. Death was significantly higher among patients with higher levels of hs-cTn I, C-RP, IL-6, and DD. hs-cTn I alone can be used as reliable biomarker in prognosis of COVID-19 and as predictor of death.

\section{AUTHORS FUNDING}

This meta-analysis was funded at our own expense.

\section{AUTHORS CONFLICT}

Authors proclaimed that no conflicts of interest were in connection with this meta-analysis.

\section{REFERENCES}

1. Hassan S, Sheikh F, Jamal S, Ezch J, Akhtar A. Coronavirus (COVID-19): A review of clinical features, diagnosis, and treatment.
Cureus 2020;12:e7355

2. Barry J, Barth J, Howell S. Cardiac troponins: Their use and relevance in anaesthesia and critical care medicine. Contin Educ Anaesth Crit Care Pain 2008:8:62-6.

3. Salazar J, Martinez M, Chavez-Castillo M, Nunez V, Anez R, Torres Y, et al. C-reactive protein: An in-depth look into structure, function, and regulation. Int Schl Res Notices 2014;2014:653045.

4. Hunter C, Jones S. IL-6 as a keystone cytokine in health and disease. Nat Immunol 2015;16:448-57.

5. Yao K, Zhao Y, Xiao X, Wu G, Xie R, Wang Y, et al. Analysis on clinical features of death patients with COVID-19: A retrospective, single-center study from Wuhan, China. Res Square 2020.

6. Weitz J, Fredenburgh J, Eikelboom J. A test in context: D-dimer. J Am Coll Cardiol 2017;70:2411-20.

7. Heng G, Mingli Z, Jing D, Yong Z, Wei W, Wei Z, et al. Cardiac structural and functional characteristics in patients with coronavirus disease 2019: A serial echocardiographic study. medRxiv. 2020;2020:20095885.

8. Chen X, Yan L, Zhang C. Laboratory abnormalities and risk factors associated with in-hospital death in patients with severe COVID-19. WILEY. J Clin Lab Anal 2020;34:e23467.

9. Zhang F, Yang D, Li J, Gao P, Chen T, Cheng Z, et al. Myocardial injury is associated with in-hospital mortality of confirmed or suspected COVID-19 in Wuhan, China: A single center retrospective cohort study. medRxiv 2020;2020:20040121.

10. Lu Y, Huang $\mathrm{Z}$, Wang $\mathrm{M}$, Tang $\mathrm{K}$, Wang $\mathrm{S}$, Gao $\mathrm{P}$, et al. Clinical characteristics and predictors of mortality in young adults with severe COVID-19. Ann Clin Microbiol Antimicrob 2020

11. Shi S, Qin M, Cai Y, Liu T, Shen B, Yang F, et al. Characteristics and clinical significance of myocardial injury in patients with severe coronavirus disease 2019. Eur Heart J 2020;41:2070-9.

12. Zhang F, Xiong Y, Wei Y, Hu Y, Wang F, Li G, et al. Obesity predisposes to the risk of higher mortality in young COVID-19 patients. J Med Virol 2020;92:2536-42.

13. Raad M, Dabbagh M, Gorgis S, Yan J, Chehab O, Dagher C, et al. Cardiac injury patterns and inpatient outcomes among patients admitted with COVID-19. Am J Cardiol 2020;133:154-61.

14. Zhu Q, Zhang W, Wang Q, Liu J, Wu C, Luo T, et al. Clinical characteristics and outcome of 64 patients with severe COVID-19. Chin J Tuberc Respir Med 2020;43:659-64.

15. Song Y, Gao P, Ran T, Qian H, Guo F, Chang L, et al. High inflammatory burden: A potential cause of myocardial injury in critically ill patients with COVID-19. Front Cardiovasc Med 2020;7:128.

16. Pan F, Yang L, Li Y, Liang B, Li L, Ye T, et al. Factors associated with death outcome in patients with severe coronavirus disease-19 (COVID-19): A case-control study. Int J Med Sci 2020;17:1281-92.

17. Barman H, Atici A, Sahin I, Alici G, Tekin E, Baycan O, et al. Prognostic significance of cardiac injury in COVID-19 patients with and without coronary artery disease. Coronary Artery Dis 2020;2020:1097.

18. Agrawal H, Das N, Nathani S, Saha S, Saini S, Kakar S, et al. An assessment on impact of COVID-19 infection in a gender specific manner. Stem Cell Rev Rep 2020;17:94-112.

19. Gagliardi M, Tieri P, Ortona E, Ruggieri, A. ACE2 expression and sex disparity in COVID-19. Cell Death Discov 2020;6:37.

20. Smith J, Sausville E, Girish V, Yuan M, Vasudevan A, John K, et al. Cigarette smoke exposure and inflammatory signaling increase the expression of the SARS-CoV-2 receptor ACE2 in the respiratory tract. Dev Cell 2020;53:514-29.e3.

21. Zeng F, Dai C, Cai P, Wang J, Xu L, Li J, et al. A comparison study of SARS-CoV-2 IgG antibody between male and female COVID-19 patients: A possible reason underlying different outcome between sex. J Med Virol 2020;92:2050-4.

22. Nguyen L, Ramanathan M, Weinstock-Guttman B, Baier M, Brownscheidle C, Jacobs L. Sex differences in vitro pro-inflammatory cytokine production from peripheral blood of multiple sclerosis patients. J Neurol Sci 2003;209:93-9.

23. Kang SJ, Jung SI. Age-related morbidity and mortality among patients with COVID-19. Infect Chemother 2020;52:154-64.

24. Tay MZ, Poh CM, Rénia L, MacAry PA, Ng LFP. The trinity of COVID-19: Immunity, inflammation and intervention. Nat Rev Immunol 2020;20:363-74.

25. Ho F, Petermann-Rocha F, Gray S, Jani B, Katikireddi S, Niedzwiedz C, et al. Is older age associated with COVID-19 mortality in the absence of other risk factors? PLoS One 2020;2020:0241824.

26. Huang C, Wang Y, Li X, Ren L, Zhao J, Hu Y, et al. Clinical features of patients infected with 2019 novel coronavirus in Wuhan, China. Lancet 2020;395:497-506.

27. Guo T, Fan Y, Chen M, Wu X, Zhang L, He T, et al. Cardiovascular 
implications of fatal outcomes of patients with coronavirus disease 2019 (COVID-19). JAMA Cardiol 2020;5:811-8.

28. Atallah B, Mallah S, Abd elWareth L, Al Mahmeed W, Fonarow G. A marker of systemic inflammation or direct cardiac injury: Should cardiac troponin levels be monitored in COVID-19 patients? Eur Heart J Qual Care Clin Outcomes 2020;6:204-7.

29. Chen H, Li X, Marmar T, Xu Q, Tu J, Li T, et al. Cardiac troponin I associated with poor prognosis and death risk in 726 severe and critical COVID-19 patients: A retrospective cohort study. Int J Med Sci 2021;18:1474-83.

30. Ozyilmaz S, Alis E, Ermis E, Allahverdiyev S, Ucar H. Assessment of the relationship between mortality and troponin I levels in hospitalized patients with the novel coronavirus (COVID-19). Medicina 2020;56:693.

31. Shi S, Qin M, Shen B, Cai Y, Liu T, Yang F, et al. Association of cardiac injury with mortality in hospitalized patients with COVID-19 in Wuhan, China. JAMA Cardiol 2020;5:802-10.

32. Hantoosh S, Zageer D, Jaber M. Role of body fat distribution, tan of skin, type of food intake and caffeine intake in infertility for polycystic ovarian syndrome women. Saudi J Med 2017;2:161-71.

33. Wang Y, Zheng Y, Tong Q, Wang L, Lv G, Xi Z, et al. Cardiac injury and clinical course of patients with coronavirus disease 2019. Front Cardiovasc Med 2020;7:147.

34. Yan L, Zhang HT, Goncalves J, Xiao Y, Wang M, Guo Y. An interpretable mortality prediction model for COVID-19 patients. Nat Mach Intell 2020;2:283-8.

35. Liu X, Shi S, Xiao J, Wang H, Chen L, Li J, et al. Prediction of the severity of corona virus disease 2019 and its adverse clinical outcomes. Jpn J Infect Dis 2020;73:404-10.

36. Caricchio R, Gallucci M, Dass C, Zhang X, Gallucci S, Fleece D, et al.
Preliminary predictive criteria for COVID-19 cytokine storm. Ann Rheum Dis 2020;2020:1-8.

37. Cummings MJ, Baldwin MR, Abrams D, Jacobson S, Meyer B, Balough E, et al. Epidemiology, clinical course, and outcomes of critically ill adults with COVID-19 in New York City: A prospective cohort study. medRxiv 2020;80:20067157.

38. Rostamian A, Ghazanfari T, Arabkheradmand J, Edalatifard M, Ghaffarpour S, Saleh M. Iran COVID-19: Immunological study: Remarkable level of interleukin-6 in Iranian COVID-19 hospitalized patients. SSRN Electron J 2020;2020:3571554.

39. Ruan Q, Yang K, Wang W, Jiang L, Song J. Clinical predictors of mortality due to COVID19 based on an analysis of data of 150 patients from Wuhan, China. Intensive Care Med 2020;46:846-8.

40. kuba K, Imai Y, Rao S, Gao H, Guo F, Guan B, et al. A crucial role of angiotensin converting enzyme 2 (ACE2) in SARS-coronavirusinduced lung injury. Nat Med 2005; 11:875-9.

41. Gorham J, Moreau A, Corazza F, Peluso L, Ponthieux F, Talamonti M, et al. Interleukin-6 in critically ill COVID-19 patients: A retrospective analysis. PLoS One 2020;15:e0244628.

42. Guan WJ, Ni ZY, Hu Y, Liang WH, Ou CQ, He JX. Clinical characteristics of coronavirus disease 2019 in China. N Engl J Med 2020;382:1708-20

43. Lin Z, Long F, Yang Y, Chen X, Xu L, Yang M. Serum ferritin as an independent risk factor for severity in COVID-19 patients. J Infect 2020;81:647-579.

44. Hantoosh S, Al Jumaili F, Zageer D. Measurement of serum lipid profile parameters, blood urea nitrogen, serum uric acid and serum creatinine levels for children with acute lymphoblastic leukemia. Asian J Biochem Genet Mol Biol 2018;1:329639. 